Supplement of Biogeosciences, 14, 4829-4850, 2017

https://doi.org/10.5194/bg-14-4829-2017-supplement

(C) Author(s) 2017. This work is distributed under

the Creative Commons Attribution 3.0 License.

(c) (1)

Supplement of

\title{
Global consequences of afforestation and bioenergy cultivation on ecosystem service indicators
}

\author{
Andreas Krause et al. \\ Correspondence to: Andreas Krause (andreas.krause@ kit.edu)
}

The copyright of individual parts of the supplement might differ from the CC BY 3.0 License. 


\section{S1 Conversion of IMAGE and MAgPIE land-use data to LPJ-GUESS input data}

Land-cover and crop transitions provided by the LUMs were converted to a suitable format to be used as input data for LPJGUESS simulations. Both LUMs provided the fraction of cropland (land used for food and bioenergy production), pasture, forest, other natural land and built-up area in a $0.5^{\circ}$ x $0.5^{\circ}$ raster from 1901 to 2100 , summing to one. Cropland and pasture land covers for LPJ-GUESS were directly adopted from the LUMs. On natural land, LPJ-GUESS simulates the dynamics of trees and grasses simultaneously as a function of environmental conditions, so the "forest" and "other natural" land covers were merged. IMAGE also uses a "degraded forest" land cover which is assumed to be completely deforested in IMAGE. To ensure consistency between the models we thus converted the corresponding fraction to pastures in LPJ-GUESS. Built-up area was negligible for all scenarios and for simplicity was also attributed to natural vegetation.

IMAGE used yearly (1970-2100) fractions of 7 food crops (each separated into rain-fed and irrigated fractions) and rain-fed bioenergy grass in each grid cell where cropland existed. MAgPIE provided yearly (1995-2100) fractions of 17 nonbioenergy crop types (separated into rain-fed and irrigated) and two rain-fed bioenergy crop types (grassy and woody). The attribution between LPJ-GUESS CFTs and LUM crop types is shown in Table S1. For the years in which the LUMs did not provide CFT fractions (1901-1994 for MAgPIE and 1901-1969 for IMAGE) ratios were taken from the first provided year. We made the attribution to $\mathrm{C}_{3}$ or $\mathrm{C}_{4}$ grass in croplands based on a preceding pasture-only simulation which was forced by the same environmental conditions as our actual simulations (RCP2.6). Dedicated bioenergy crops are currently not implemented in LPJ-GUESS and were represented by corn. Removed residues of bioenergy crops (90\%) were included in the CCS calculation (see Supplement S2), while removed residues of food crops (75\%) were emitted to the atmosphere. Residues left on-site (10\% and 25\%, respectively) went to the litter.

Average annual $\mathrm{N}$ fertilizer rates per cropland area (synthetic and organic fertilizer, derived from yields) were provided by IMAGE (1970-2100) and MAgPIE (1995-2100) and had to be extended to year 1901. Historic N fertilizer rates (synthetic fertilizer on $\mathrm{C}_{3}+\mathrm{C}_{4}$ annual and perennial crops) were available from the recently released LUH2 data set (Hurtt et al, in preparation, http://luh.umd.edu/index.shtml). However, as LUH2 only considers synthetic fertilizer, the correlation between LUH2 and the LUMs in the first provided year was poor in terms of spatial patterns and total amount of applied N, making a simple merging inapplicable. We thus decided to use IMAGE and MAgPIE $\mathrm{N}$ fertilizer rates and spatial patterns for the available time periods and computed a historic hindcast, starting with the initial spatial patterns and rates in IMAGE and MAgPIE multiplied by the relative year-to-year per-country change in the LUH2 data set in the period prior to 1970 and 1995, respectively. This resulted in a smooth historical to future $\mathrm{N}$ fertilizer dataset reflecting the LUMs spatial patterns in terms of absolute values with historic variations based on LUH2 relative changes and late historic to future variations adopted unmodified from the LUMs. Fertilizer rates differed significantly between IMAGE and MAgPIE, with MAgPIE exceeding IMAGE fertilizer rates in most locations. As no fertilization occurred before 1916 in LUH2 (before the Haber- 
Bosch process was found), we applied a minimum fertilizer rate of $6 \mathrm{~kg} \mathrm{~N} \mathrm{ha}^{-1} \mathrm{yr}^{-1}$ (in addition to atmospheric deposition) to all areas under crops throughout the entire simulation period to limit continued soil $\mathrm{N}$ depletion. As the LUMs only provided per-cropland fertilizer rates, we applied the same amount of fertilizer for all CFTs in a grid cell, and distributed the annual amount over the year as a function of crop phenological state (Olin et al., 2015).

\section{S2 Carbon storage via CCS}

Bioenergy yields included removed harvestable organs and crop residues (90\% of total above-ground biomass). We estimated the total amount of $\mathrm{C}$ sequestered via CCS in the bioenergy simulations by assuming an $80 \%$ capture rate upon oxidization, which is the same value as in the LUMs (Klein et al., 2014). The total C was then the sum of terrestrial C (vegetation, soil and litter, $\mathrm{C}$ stored in wood products) and cumulative $\mathrm{C}$ stored via CCS.

\section{S3 Albedo calculation}

We calculated January and July surface albedo mainly based on mean winter (snow-free and snow-covered) and summer albedo values for different land-cover types derived from MODIS satellite observations by Boisier et al. (2013). For the Southern Hemisphere we switched snow-free winter and summer albedo values. The LPJ-GUESS PFTs fractional plant cover determines the fraction of the grid cell occupied by the land-cover groups (crops, grasses, evergreen trees, deciduous trees, bare soil). For tropical evergreen trees we assumed an albedo of 0.140 year-round based on Boisier et al. (2013). For woody bioenergy we assumed the same albedo as deciduous forests. The albedo of the non-vegetated fraction of the grid cell under snow-free conditions was taken from Houldcroft et al. (2009) (average of white and black sky albedo), assuming a value of 0.15 at locations where no measurements were available. We estimated the grid cell's monthly fraction under snow cover $f_{\text {snow }}$ as

$f_{\text {snow }}=\frac{z_{\text {sn }}}{0.01+z_{\text {sn }}}$

where $z_{\mathrm{sn}}$ is the average monthly snow depth (m) (Wang and Zeng, 2010, equation 17) which can be output from LPJGUESS. The albedo of the snow-covered fraction was calculated based on the values from Boisier et al. (2013) for snowcovered vegetation and bare soil and the grid cell albedo was then the area-weighted average of snow-covered and snow-free albedos.

\section{S4 Crop yield scaling}

To account for spatial variations in crop management other than irrigation and fertilization, which are not accounted for in LPJ-GUESS, we scaled our food crop yields to the actual yields from the EarthStat data set (Monfreda et al., 2008), thereby only taking the absolute year-to-year changes from LPJ-GUESS. For this, we re-scaled yields of our 4 food CFTs (temperate 
wheat, temperate other summer crops, rice, corn) around the year 2000 (1997-2003) to match actual yields based on areaweighted yields of major food crops in the EarthStat data set (aggregated to $0.5^{\circ} \mathrm{x} 0.5^{\circ}$ resolution; see Table S1 for which crop types were aggregated to which CFT). We then used these actual yields over the full crop yield time series, with yearto-year variations calculated based on the yield changes in LPJ-GUESS (area-weighted between rain-fed and irrigated yields). If crops were present in the LUMs but no adequate crop types were available in the EarthStat data set for a grid cell we took the yields unmodified from LPJ-GUESS. We first converted dry matter yields per $\mathrm{m}^{2}$ as given by LPJGUESS/EarthStat to fresh matter yields and finally to kcal. Fodder and cotton were not used for the crop production calculation. Total crop production was then the sum of temperate wheat, temperate other summer crops, rice and nonbioenergy corn production. Yields of bioenergy crops (grown as corn) were used unmodified to estimate CCS (see Supplement S2) due to limited observational data of bioenergy crop yields.

\section{S5 BVOC emission factors of bioenergy crops}

Crop BVOC basal emission factors were taken from natural $\mathrm{C}_{3}$ or $\mathrm{C}_{4}$ grass, apart from woody bioenergy crops, which we grew as corn but used isoprene basal emission factors of $45 \mu \mathrm{g}(\mathrm{C}) \mathrm{g}^{-1}$ (leaf foliar mass) $\mathrm{h}^{-1}$ (Ashworth et al., 2012). These values are much higher than the values for normal grasses $\left(8 \mu \mathrm{g} \mathrm{g}^{-1} \mathrm{~h}^{-1}\right.$ for $\mathrm{C}_{4}$ grasses and $16 \mu \mathrm{g} \mathrm{g}^{-1} \mathrm{~h}^{-1}$ for $\mathrm{C}_{3}$ grasses) and account for the fact that isoprene emissions from typical woody bioenergy species like oil palm or willow are very high. 
Table S1: Crop functional types (CFTs) used in this study, how the LU models' crop types were aggregated to these CFTs, and EarthStat major crops used to calculate circa year 2000 actual yields of these CFTs.

\begin{tabular}{|c|c|c|}
\hline $\begin{array}{l}\text { LPJ-GUESS CFT } \\
\text { (photosynthetic } \\
\text { pathway) }\end{array}$ & $\begin{array}{l}\text { IMAGE and MAgPIE crop types aggregated to } \\
\text { this CFT }\end{array}$ & $\begin{array}{l}\text { EarthStat major crop types used to } \\
\text { calculate circa year } 2000 \text { actual } \\
\text { yields of LPJ-GUESS crops }\end{array}$ \\
\hline $\begin{array}{l}\text { temperate wheat } \\
\left(C_{3}\right) \text {, representing } C_{3} \\
\text { crops with winter or } \\
\text { spring sowing } \\
\text { depending on } \\
\text { historical climate }\end{array}$ & temperate cereals, rapeseed & rye, barley, wheat, rapeseed \\
\hline $\begin{array}{l}\text { temperate other } \\
\text { summer crops }\left(C_{3}\right) \\
\text { representing } C_{3} \text { crops } \\
\text { with spring sowing } \\
\text { only }\end{array}$ & $\begin{array}{l}\text { potatoes, cassava, pulses, soybean, groundnuts, } \\
\text { sunflower, palm oil, sugar beet, cotton, roots and } \\
\text { tubers, oil crops, others }\end{array}$ & $\begin{array}{l}\text { potato, cassava, groundnut, } \\
\text { soybean, sunflower, oilpalm }\end{array}$ \\
\hline rice $\left(\mathrm{C}_{3}\right)$ & (paddy) rice & rice \\
\hline $\operatorname{corn}\left(\mathrm{C}_{4}\right)$ & $\begin{array}{l}\text { maize, tropical cereals, sugarcane, bioenergy } \\
\text { crops }\end{array}$ & $\begin{array}{l}\text { maize, millet, sorghum, sugarcane; } \\
\text { bioenergy yields were not modified } \\
\text { due to limited observational data }\end{array}$ \\
\hline crop grass $\left(\mathrm{C}_{3}\right.$ or $\left.\mathrm{C}_{4}\right)$ & fodder & $\begin{array}{l}\text { unmodified as not used for crop } \\
\text { production calculation }\end{array}$ \\
\hline
\end{tabular}

Table S2: Global area (Mha) under natural vegetation, pasture (parentheses: degraded forests) and cropland (parentheses: bioenergy) for the different scenarios for the 2000-2009 and 2090-2099 periods.

\begin{tabular}{|l|l|l|l|l|l|l|}
\hline \multirow{2}{*}{ Scenario (year) } & \multicolumn{3}{|c|}{ IMAGE } & \multicolumn{3}{c|}{ MAgPIE } \\
\cline { 2 - 7 } & Natural & Pasture & Cropland & Natural & Pasture & Cropland \\
\hline BASE (2000-2009) & 8155 & $3584(313)$ & 1569 & 8367 & 3332 & 1609 \\
\hline BASE (2090-2099) & 7664 & $3974(551)$ & 1671 & 8225 & 3073 & 2010 \\
\hline ADAFF (2090-2099) & 8783 & $2879(14)$ & 1645 & 9139 & 2832 & 1338 \\
\hline BECCS (2090-2099) & 7162 & $3981(551)$ & $2165(493)$ & 8074 & 3015 & $2219(363)$ \\
\hline BECCS-ADAFF (2090-2099) & 8119 & $3307(14)$ & $1882(254)$ & 8561 & 2964 & $1783(158)$ \\
\hline
\end{tabular}



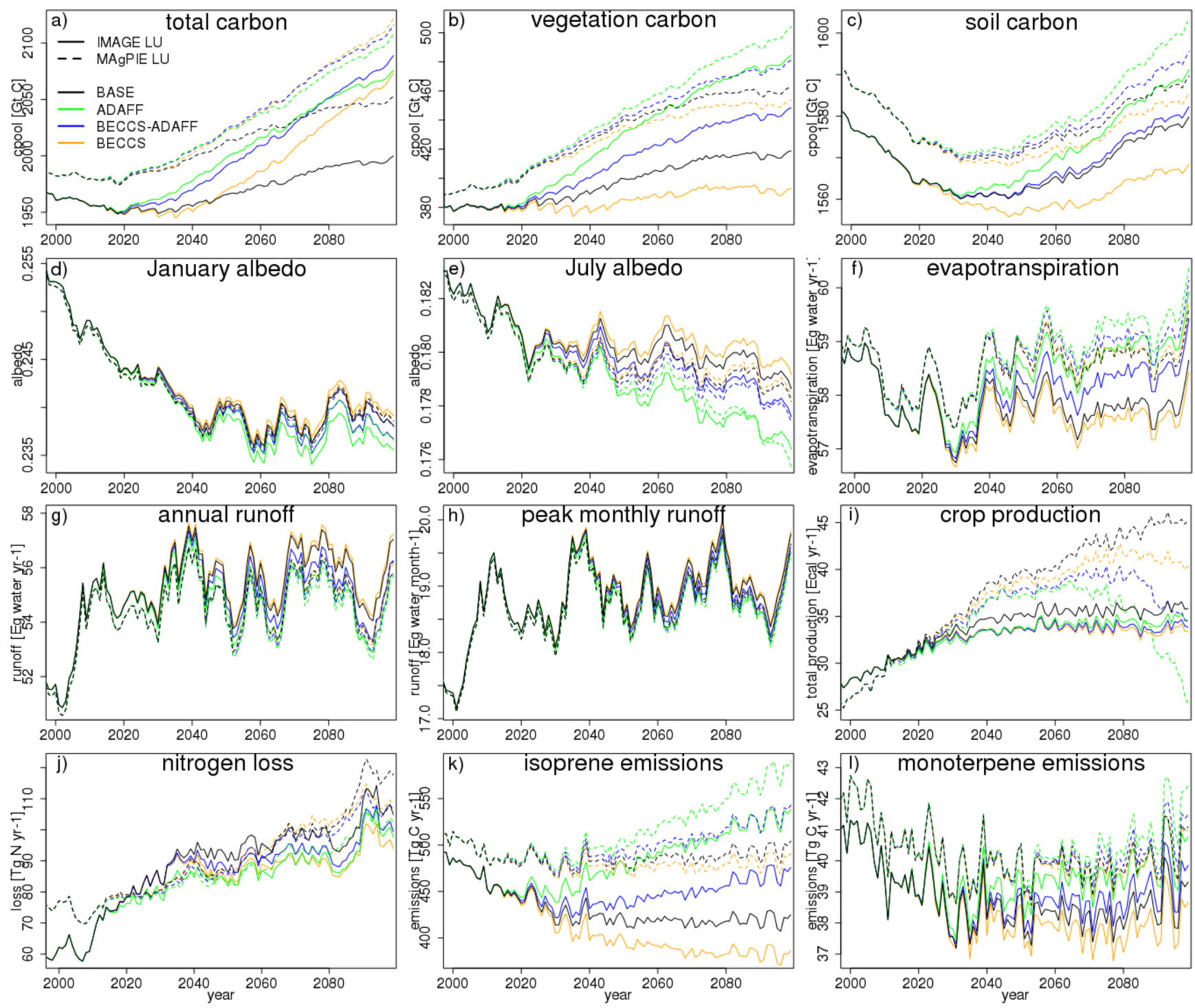

Figure S1: Time series (2000-2099) of ecosystem functions as simulated by LPJ-GUESS for all scenarios, area-weighted and summed/averaged over all grid cells. a) total carbon pool (terrestrial carbon, including CCS for bioenergy scenarios), b) vegetation carbon pool, c) soil and litter carbon pool, d) January albedo (5-year running mean), e) July albedo (5-year running mean), f) evapotranspiration (5-year running mean), g) annual runoff (5-year running mean), h) peak monthly runoff (5-year running mean), i) crop production, j) nitrogen loss (5-year running mean), $\mathrm{k}$ ) isoprene emissions, 1) monoterpene emissions. 
BASE $2000-2009 \rightarrow$ BASE 2090-2099

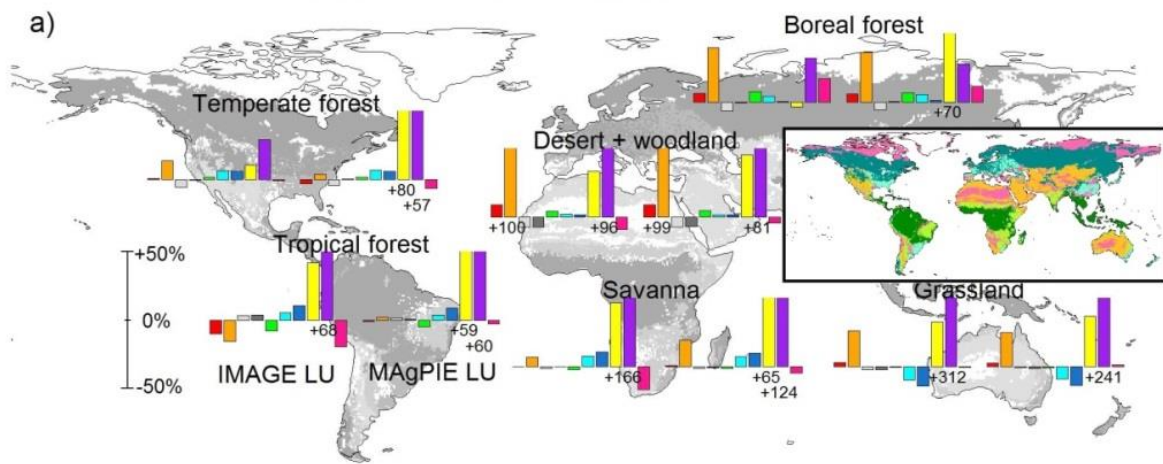

BASE 2090-2099 $\rightarrow$ ADAFF 2090-2099

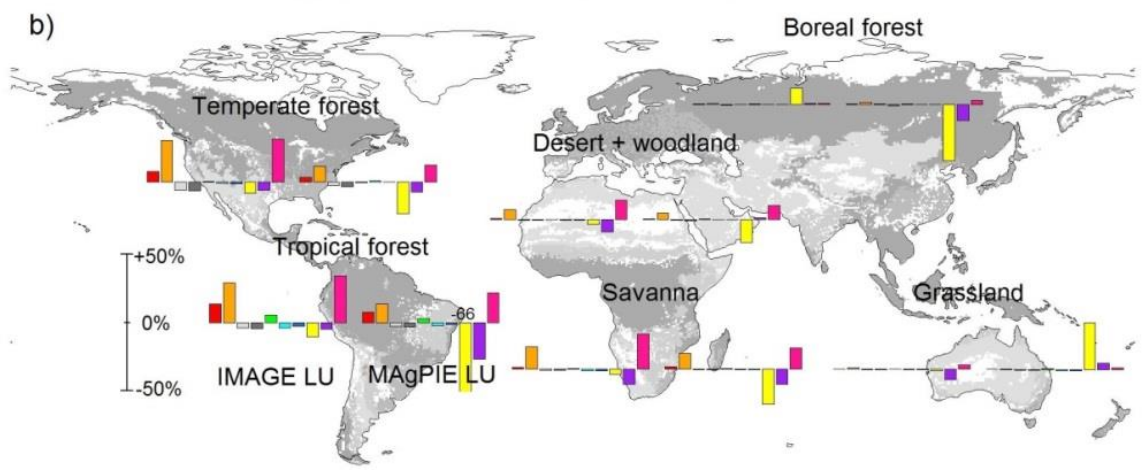

\section{BASE 2090-2099 $\rightarrow$ BECCS 2090-2099}

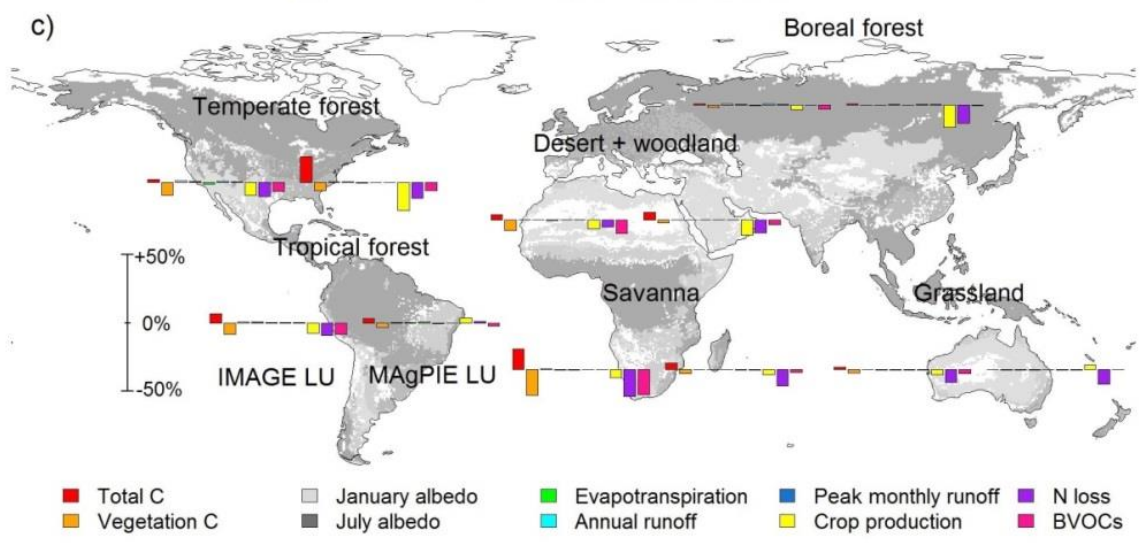

Figure S2: Same as Fig. 4 but changes shown for different biomes rather than Global Fire Emissions Database regions. Biomes are aggregated from the biomes used in Smith et al. (2014): tundra+desert+woodland+shrubland; dry+moist savanna; dry and tall grassland; tropical forest; temperate forest; boreal+temperate/boreal mixed forest. The LAI map used for the biome classification was taken from the LPJG $_{\text {MAgPIE }}$ BASE simulation and the 2000-2009 period. The coloured snapshot in a) shows the same biomes as the grey-coloured biomes in the larger maps to facilitate differantiation. 


\section{BASE 2090-2099 $\rightarrow$ BECCS-ADAFF 2090-2099}

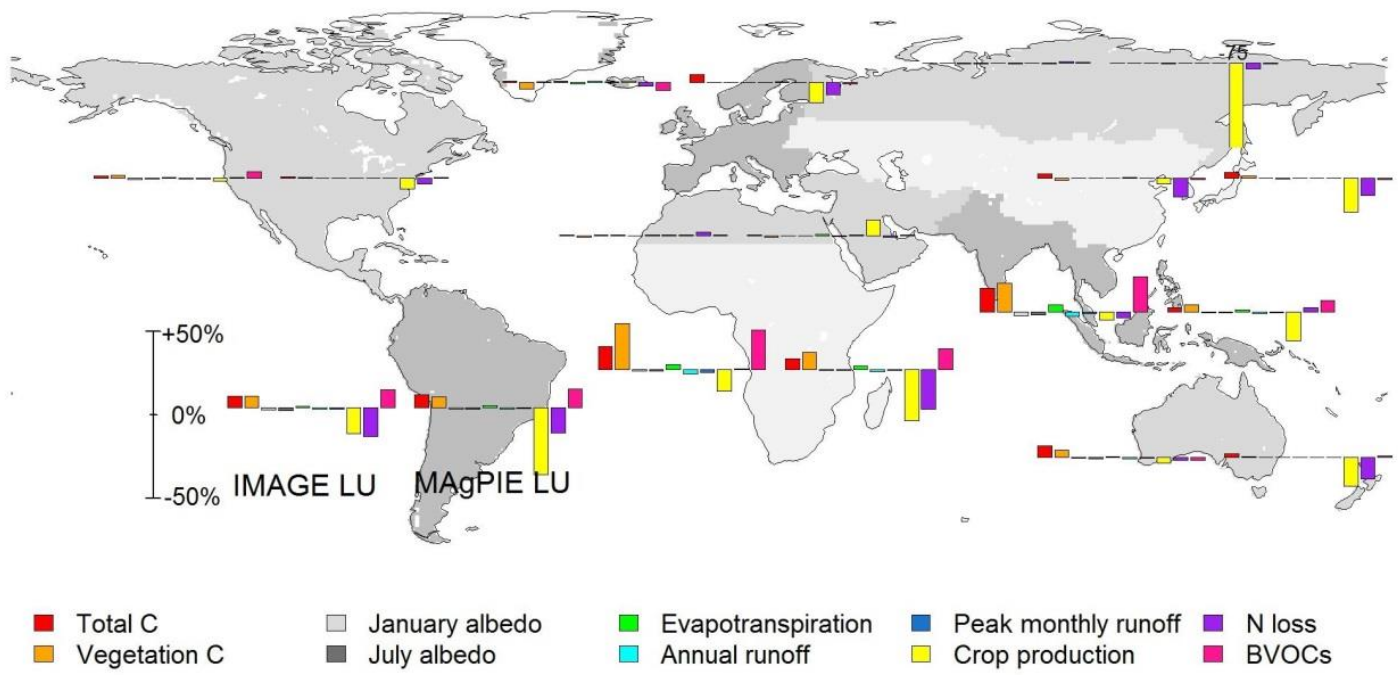

Figure S3: Regional relative changes in analysed ecosystem functions as simulated by LPJ-GUESS for IMAGE-LU (left) and MAgPIELU (right) from BASE to BECCS-ADAFF by the 2090-2099 period. Changes are capped at $\pm 50 \%$ for clarity reasons, values exceeding $\pm 50 \%$ are written upon/below the bar. The decrease in crop production might occur if increases in crop yields cannot be realized. Regions are aggregated Global Fire Emissions Database regions (Giglio et al., 2010).
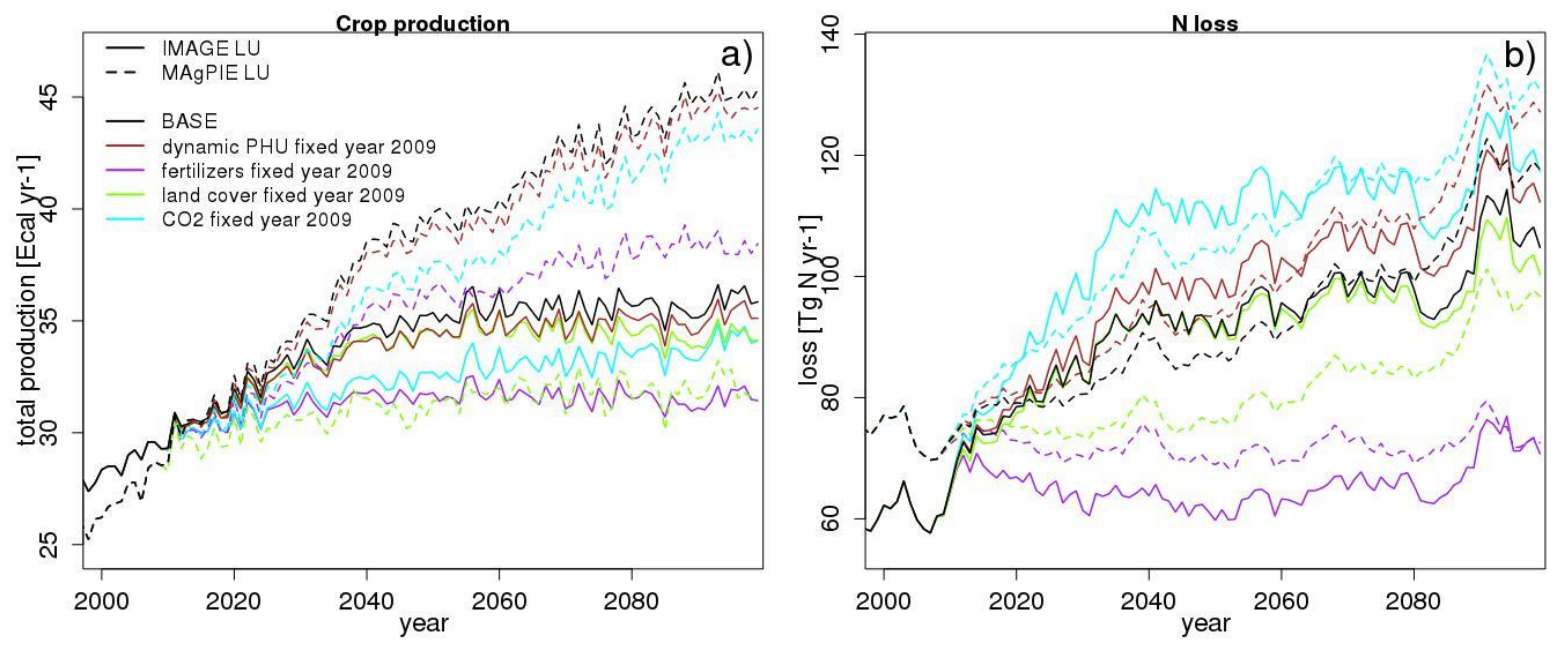

Figure S4: Impacts of fixing nitrogen fertilizers, crop area, dynamic PHU calculation (i.e. adaption to climate change via selecting suitable varieties) and atmospheric $\mathrm{CO}_{2}$ concentration at year 2009 levels on LPJ-GUESS crop production (a) and nitrogen loss (b), for the BASE simulations. 

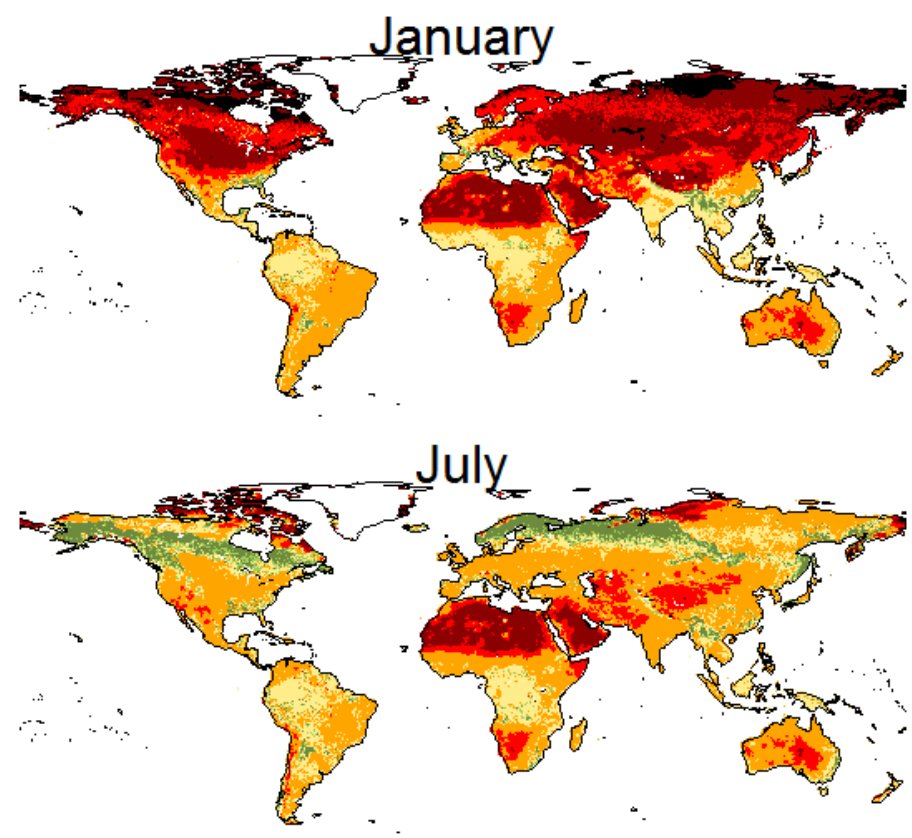

Surf. albedo (x100)

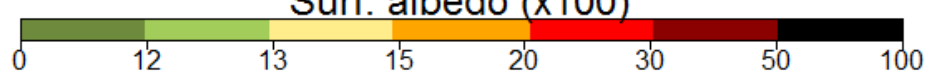

Figure S5: Mean surface albedo in January (top) and July (bottom) in LPJG et al. (2013)

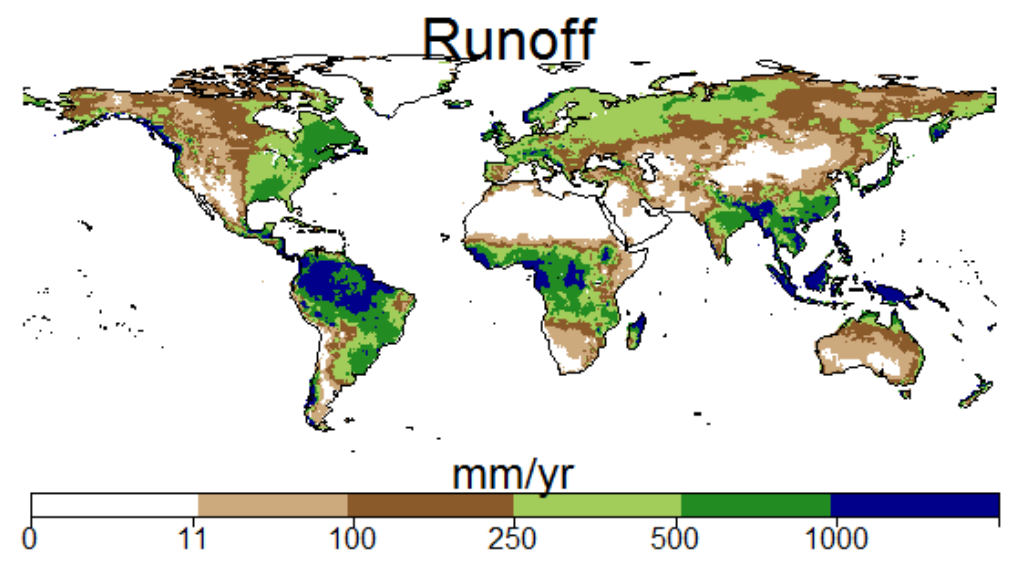

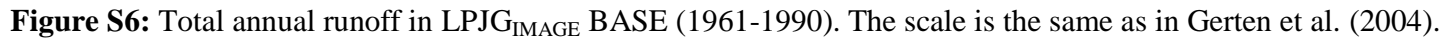




\section{Supplementary References}

Ashworth, K., Folberth, G., Hewitt, C. N., and Wild, O.: Impacts of near-future cultivation of biofuel feedstocks on atmospheric composition and local air quality, Atmos Chem Phys, 12, 919-939, doi:10.5194/acp-12-919-2012, 2012.

Boisier, J. P., de Noblet-Ducoudre, N., and Ciais, P.: Inferring past land use-induced changes in surface albedo from satellite observations: a useful tool to evaluate model simulations, Biogeosciences, 10, 1501-1516, doi:10.5194/bg-10-1501-2013, 2013.

Gerten, D., Schaphoff, S., Haberlandt, U., Lucht, W., and Sitch, S.: Terrestrial vegetation and water balance - hydrological evaluation of a dynamic global vegetation model, J Hydrol, 286, 249-270, doi:10.1016/j.jhydrol.2003.09.029, 2004.

Giglio, L., Randerson, J. T., van der Werf, G. R., Kasibhatla, P. S., Collatz, G. J., Morton, D. C., and DeFries, R. S.: Assessing variability and long-term trends in burned area by merging multiple satellite fire products, Biogeosciences, 7 , 1171-1186, doi:10.5194/bg-7-1171-2010, 2010.

Houldcroft, C. J., Grey, W. M. F., Barnsley, M., Taylor, C. M., Los, S. O., and North, P. R. J.: New Vegetation Albedo Parameters and Global Fields of Soil Background Albedo Derived from MODIS for Use in a Climate Model, J Hydrometeorol, 10, 183-198, doi:10.1175/2008JHM1021.1, 2009.

Klein, D., Luderer, G., Kriegler, E., Strefler, J., Bauer, N., Leimbach, M., Popp, A., Dietrich, J. P., Humpenoder, F., LotzeCampen, H., and Edenhofer, O.: The value of bioenergy in low stabilization scenarios: an assessment using REMINDMAgPIE, Climatic Change, 123, 705-718, doi:10.1007/s10584-013-0940-z, 2014.

Monfreda, C., Ramankutty, N., and Foley, J. A.: Farming the planet: 2. Geographic distribution of crop areas, yields, physiological types, and net primary production in the year 2000, Global Biogeochem Cy, 22, doi:10.1029/2007gb002947, 2008.

Olin, S., Schurgers, G., Lindeskog, M., Warlind, D., Smith, B., Bodin, P., Holmer, J., and Arneth, A.: Modelling the response of yields and tissue $\mathrm{C}: \mathrm{N}$ to changes in atmospheric $\mathrm{CO} 2$ and $\mathrm{N}$ management in the main wheat regions of western Europe, Biogeosciences, 12, 2489-2515, doi:10.5194/bg-12-2489-2015, 2015.

Smith, B., Warlind, D., Arneth, A., Hickler, T., Leadley, P., Siltberg, J., and Zaehle, S.: Implications of incorporating N cycling and $\mathrm{N}$ limitations on primary production in an individual-based dynamic vegetation model, Biogeosciences, 11, 2027-2054, doi:10.5194/bg-11-2027-2014, 2014.

Wang, Z., and Zeng, X. B.: Evaluation of Snow Albedo in Land Models for Weather and Climate Studies, J Appl Meteorol Clim, 49, 363-380, doi:10.1175/2009JAMC2134.1, 2010. 